FULL LENGTH RESEARCH ARTICLE

\section{SUITABILITY OF SORGHUM GRAIN FOR THE DEVELOPMENT OF THE LARGER GRAIN BORER Prostephanus truncatus (HORN) (COLEOPTERA: BOSTRICHIDAE)}

\author{
*MAILAFIYA, D. M. ${ }^{1,4}{ }^{4}$, AYERTEY, J. N. ${ }^{2} \&$ CUDJOE, A. R \\ ${ }^{1}$ Department of Crop Protection \\ Faculty of Agriculture, P.M.B. 1069 \\ University of Maiduguri, Nigeria \\ ${ }^{2}$ Department of Crop Science \\ Faculty of Agriculture, P. O. Box LG 44 \\ University of Ghana, Legon \\ ${ }^{3}$ Plant Protection and Regulation Services \\ Ministry of Food and Agriculture, Ghana \\ ${ }^{4}$ Environmental Health Division \\ International Centre of Insect Physiology and Ecology (icipe) \\ P. O. Box 30772-00100, Nairobi, Kenya \\ *(Corresponding author) \\ dmailafiya@icipe.org
}

\begin{abstract}
Laboratory studies were carried out to determine the development of the Larger grain borer Prostephanus truncatus (Horn) (Coleoptera: Bostrichidae) on sorghum grain. Substrate suitability, susceptibility and preference tests were conducted. Tests were conducted using $P$. truncatus on 3 sorghum (2 high-yield [Framida and Naga-White] and 1 native [mankaraga]) and 1 maize (native) cultivars. The beetle successfully completed its life cycle on sorghum grain, when stored as whole grain or finely ground grain flour. However, the beetle failed to develop on sorghum grain, when stored as coarsely ground grain. Mean development period of the grain borer was 36 to 60 days and differed with substrate type and grain cultivar. Mean number of first generation $\left(F_{1}\right)$ adult beetles recovered ranged from 1.51 to 13.6 individuals. In a similar manner, the mean weight of beetles produced ranged from 1.70 to $3.02 \mathrm{mg}$. Furthermore, $P$. truncatus showed higher preference for the high-yield improved sorghum cultivars (Framida \& Naga-White) than the native one (Mankaraga). These high-yield improved sorghum cultivars were also more susceptible to attack by the stem borer. These cultivars have relatively soft pericarp and endosperm texture which offered low resistance to the boring and tunneling activities of these beetles. This indicates that in the absence of its most preferred host (maize), $P$. truncatus can subsist on sorghum grain. Thus sorghum grain can serve as a reservoir for $P$. truncatus. These findings should be exploited when designing biological control programmes in sorghum growing regions of sub-Saharan Africa.
\end{abstract}

Keywords: Prostephanus truncatus, sorghum grain, substrate suitability, susceptibility index, grain preference, biological control

\section{INTRODUCTION}

The bostrichid beetle Prostephanus truncatus Horn 1878 was accidentally introduced from its area of origin in Mexico and Central America into East Africa in the late 1970s and West Africa in the early 1980s (Dunstan \& Magazini 1981; Harnisch \& Krall 1984). The beetle has since spread to at least 17 countries (Roux 1999; Farrell 2000) and has become the major pest of stored maize and cassava in subSaharan Africa, responsible for losses in weight of stored maize of up to $30 \%$ (Farrell \& Schulten 2002). Initial control strategies focused on fumigants and insecticides, but for socio-economic reasons, chemical control strategy was not widely adopted by subsistence farmers (Agbaka 1996). Hence, a biological control agent, Teretrius nigrescens Lewis 1906 was introduced in various parts of Africa (Henning-Helbig 1995; Bell et al. 1999). However, lack of control has been reported already from Benin (Meikle et al. 2002) and Ghana (Birkinshaw \& Hodges 2000).

Sorghum (Sorghum bicolor (L.) Moench 1936) is a viable food grain for people in Africa (FAO 2003; Gwary \& Asala 2006). The grain is used in making instant soft porridge, malt extracts and as an alternative to barley for lager beer brewing. Unfortunately, it is among the crops most preferred by storage pests, and attacked by several species (Ayertey \& Padi 1996)

Prostephanus truncatus is an outbreak pest causing spectacular damage and losses in Africa. Although much work has been conducted on the biology, ecology and its control on maize and cassava (Dick 1988; McFarlane 1988; Holst \& Meikle 2003), there is very little information on the biology and ecology of this pest on sorghum grain. Effective and sustainable biological control or Integrated Pest Management (IPM) approach to manage $P$. truncatus in sub-Saharan Africa can only be attained with sufficient knowledge of the complex biology and ecology of this beetle. This experiment was initiated to investigate the suitability of sorghum grain as a breeding substrate for $P$. truncatus.

\section{MATERIALS AND METHODS}

Insect cultures: Laboratory studies were conducted at the Plant Protection and Regulation Services, Ministry of Food and Agriculture (PPRS/MOFA), Pokuase, Accra, Ghana. Initial laboratory cultures of $P$. truncatus were set up with individuals collected from the stock at PPRS/MOFA in Kpeve, Volta Region, Ghana. In each $1000 \mathrm{ml}$ glass jars, $300 \mathrm{~g}$ of shelled maize was infested with 100 unsexed adult beetles and kept covered with a metal screen. All adult beetles were removed after 2 weeks to obtain a synchronized $F_{1}$ progeny.

Maize \& Sorghum cultivars: One maize (Obatanpa [native]) and 3 sorghum (Framida [high-yield], Mankaraga [native] and Naga-White [high-yield]) cultivars were obtained from the Savannah Agricultural Research Institute (SARI), Council for Scientific and Industrial Research (CSIR), Tamale, Ghana. Undamaged grains were deep frozen for 2 weeks and then thermally sterilized at $45{ }^{\circ} \mathrm{C}$ for $4 \mathrm{hrs}$ in a laboratory air-oven (Santhoy \& Rejesus 1975). The grains were sterilized and conditioned for 21 days in the laboratory at 32 ${ }^{\circ} \mathrm{C} \pm 3^{\circ} \mathrm{C}$ and $81 \% \pm 5 \% \mathrm{RH}$ under a $12 \mathrm{hr}$ photoperiod.

Substrate suitability: About $100 \mathrm{~g}$ each of whole grains, coarsely ground grain and finely ground grain flour were kept in $500 \mathrm{ml}$ glass jars. Each jar was infested with 20 unsexed adult beetles aged between 0-7 days old. 14 days post oviposition, the adult beetles were sieved out (Endecott sieves). Each treatment (substrate type) was replicated 5 times. The development period of the beetles was recorded as the time in days taken from the mid-point of oviposition 
period to the time of emergence of $50 \%$ of the $F_{1}$ generation adult beetles.

Grain susceptibility was determined as described by Dobie (1974), where susceptibility index $=\log e$ of the number of $F_{1}$ generation adults divided by mean development period multiplied by 100 . Each adult beetle was weighed within 24 hrs of emergence using an electronic digital balance (Cahn 29) with an accuracy of $0.001 \mathrm{mg}$

Grain properties: The length and breadth $(\mathrm{mm})$ of 50 grains per cultivar were measured with the aid of a digimatic caliper (Baty). Measurements were replicated 5 times per cultivar. One-thousand grain weight was determined by weighing 1000 grains of each cultivar. Measurements were also replicated 5 times per cultivar. To determine grain density, 50 grains per cultivar were poured into a $250 \mathrm{ml}$ graduated cylinder filled with $100 \mathrm{ml}$ of $95 \%$ ethanol. Grain density of each cultivar was calculated as the weight of grain divided by the volume of ethanol displaced. Grain hardness was determined as described by Pomeranz et al. (1985) with the aid of Hounsfield Tensile Strength Machine. Fifty-grain samples of all cultivars were equilibrated for 14 days in a humidity chamber maintained at $30^{\circ} \mathrm{C}$ and $70 \% \mathrm{RH}$. Using the tensile strength machine, the compression force (Newton [N]) that cracked each individual grain was recorded per cultivar. Measurements were replicated 5 times per cultivar. Grain endosperm texture was determined using the 'Grind and Sieve Method' as described by Davey (1965). Fifty grain sample per cultivar was equilibrated as mentioned above. The grains were ground at a constant setting in a laboratory mill (Christy and Norris Hammer), the flour was then sieved through a $500 \mu \mathrm{m}$ mesh (Endecott sieve). Percentage fraction of floury/corneous endosperm $=$ weight of grains retained in the sieve $(\mathrm{g})$ divided by the sum of the weight of grains that passed through the sieve $(\mathrm{g})$ and weight of grains retained in the sieve (g) multiplied by 100 .

Preference test: Grain preference by $P$. truncatus was determined as described by Chijindu (2002). For each cultivar, a 50 grain sample was placed on $10 \mathrm{~mm}$ diameter filter paper in a Petri-dish. Petri-dishes containing samples of different grain cultivars were arranged in a circular pattern, at least $10 \mathrm{~cm}$ apart, in an enclosed transparent trough. Forty adult beetles were then introduced in a separate Petridish at the centre of the trough to allow the beetles move freely to any cultivar of their choice. Observations were conducted at $4 \mathrm{hr}$ intervals for a total of $16 \mathrm{hrs}$. On each occasion, the number of beetles found on each grain variety was recorded. This experiment was replicated 5 times.

Data analysis: All experiments were arranged in a complete block design. Count data were $\log (\log [x+1])$ transformed (Zar 1999). All data were subjected to analysis of variance (ANOVA), using SAS software (version 6)(SAS 1989). The means of cases that were significantly different $(P<0.05)$ were separated using StudentNewman-Keul (SNK) Test.

\section{RESULTS}

Sorghum grain: Mean development time of $P$. truncatus on whole grain was significantly $(P<0.001)$ shorter on the high-yield cultivars (Framida \& Naga-White) than on the native one (Mankaraga) (Table 1). The beetles could not develop on coarsely ground sorghum grains. Developmental time was much longer on finely ground grain flour. On grain flour, the development period of the beetles was significantly shorter $(P<0.005)$ on the high-yield cultivars (Framida \& Naga-White) than on the native one (Mankaraga). The mean number of $F_{1}$ generation adult beetles was higher on whole grain than on grain flour (Table 2). Irrespective of the substrate type, mean number of $F_{1}$ generation adult beetles were significantly $(P<0.001)$ higher on highyield cultivars (Framida \& Naga-White) than on the native one (Mankaraga) (Table 2). Mean weight values of adult beetles were fairly similar on both whole grain and grain flour (Table 3). However, on whole grain, significantly $(P<0.001)$ heavier beetles were produced on high-yield cultivars (Framida \& Naga-White) than on the native one (Mankaraga). There were no significant $(P=0.06)$ differences in insect weight among sorghum cultivars on grain flour. Susceptibility indices were higher on whole grains than on grain flour (Table 4). On both whole grain and grain flour, susceptibility indices were higher on highyield cultivars (Framida \& Naga-White) than on the native one (Mankaraga). In a similar manner, beetles showed higher preference for the high-yield cultivars (Framida \& Naga-White) than on the native one (Mankaraga) (Table 5). There was no significant difference $(P=$ $0.12)(P=0.07)(P=0.10)$ in the mean grain length, densities and 1000-grain among sorghum cultivars, but the mean grain breadth, endosperm texture and grain hardness were significantly higher $(P<0.05)$ on high-yield cultivars (Framida \& Naga-White) than on the native one (Mankaraga).

Maize grain: Mean development time of $P$. truncatus was significantly faster $(P<0.001)$ on maize than on sorghum grain (Table 1$)$ Considering the substrate types, the development of the beetles was much longer on grain flour than on whole grain. Mean weight values of adult beetles were fairly similar on both whole grain and grain flour (Table 1). However, compared to sorghum, mean weight of adult beetles was significantly $(P<0.001)$ heavier on maize when stored as grain flour. The mean number of $F_{1}$ generation adult beetles susceptibility indices, varietal preference, grain length/breadth, endosperm texture and grain hardness were exceedingly significantly higher on maize than on sorghum grain (Tables 1-6).

\section{DISCUSSION}

These results from this study indicate that $P$. truncatus can complete its development from egg to adult stage on sorghum grain. The beetle also completed development on whole grain and grain flour, but not on coarsely ground grain, with the development being much faster on whole grain than on grain flour. This finding contradicts previous reports that $P$. truncatus can only breed in maize and cassava (Hill 2002). The ability of the beetle to develop on sorghum grain may be due to a number of reasons. First, the large mean length of sorghum grain (4.22 to $4.57 \mathrm{~mm}$ ) probably accommodated the tunneling activities of the average size ( 3 to $4.5 \mathrm{~mm}$ ) adult borers (Haines 1991) (Table 6) and secondly, the ability of the beetle to oviposit, feed and pupate in grain flour, supporting an earlier report (Bell \& Watters 1982) that observed the pupation of the beetle in grain flour. On the contrary, coarsely ground grain proved to be an unsuitable substrate for development of borer as no adult emergence was recorded on this substrate. Given that grain size influences the survival and development of $P$. truncatus (Li 1988), insufficient size of coarsely ground grain may have deterred the beetles from breeding successfully on the coarsely ground grain substrate. Li (1998) had earlier reported that the beetle has some acoustic mechanism for appraising its host size with which it rejects regions in a substrate that have insufficient depth when selecting a suitable location to bore. 
TABLE 1. MEAN DEVELOPMENT TIME OF $P$. truncatus ON DIFFERENT GRAIN CULTIVARS AND SUBSTRATE TYPES

\begin{tabular}{|c|c|c|c|}
\hline \multirow{3}{*}{ Grain cultivar } & \multicolumn{3}{|c|}{ Mean development time (days) } \\
\hline & \multicolumn{3}{|c|}{ Substrate type } \\
\hline & $\begin{array}{l}\text { Whole } \\
\text { grain }\end{array}$ & $\begin{array}{l}\text { Coarse } \\
\text { ground grain }\end{array}$ & $\begin{array}{l}\text { Fine } \\
\text { grain flour }\end{array}$ \\
\hline Framida (sorghum) & $37.40 \pm 1.88^{b}$ & $0.00 \pm 0.00^{a}$ & $51.40 \pm 1.88^{b}$ \\
\hline Mankaraga (sorghum) & $46.60 \pm 1.16^{a}$ & $0.00 \pm 0.00^{a}$ & $60.60 \pm 1.16^{a}$ \\
\hline Naga-White (sorghum) & $36.00 \pm 3.43^{b}$ & $0.00 \pm 0.00^{a}$ & $50.00 \pm 3.43^{b}$ \\
\hline Obatanpa (maize) & $27.00 \pm 1.14^{c}$ & $0.00 \pm 0.00^{a}$ & $41.00 \pm 1.14^{c}$ \\
\hline
\end{tabular}

\section{TABLE 2. MEAN NUMBER OF $F_{1}$ GENERATION ADULT BEETLES ON DIFFERENT GRAIN CULTIVARS AND SUBSTRATE TYPES}

\begin{tabular}{llll}
\hline \multirow{2}{*}{ Grain cultivar } & \multicolumn{3}{c}{ Mean number of $\mathrm{F}_{1}$ generation } \\
\cline { 2 - 4 } & \multicolumn{3}{c}{ Substrate type } \\
\cline { 2 - 4 } & Whole & Coarse & Fine \\
& grain & $0.00 \pm 0.00^{\mathrm{a}}$ & grain flour \\
\hline Framida (sorghum) & $13.6 \pm 0.28^{\mathrm{b}}$ & $.17 \pm 0.15^{\mathrm{b}}$ \\
Mankaraga (sorghum) & $2.40 \pm 0.23^{\mathrm{a}}$ & $0.00 \pm 0.00^{\mathrm{a}}$ & $1.51 \pm 0.16^{\mathrm{a}}$ \\
Naga-White (sorghum) & $11.0 \pm 0.29^{\mathrm{b}}$ & $0.00 \pm 0.00^{\mathrm{a}}$ & $2.33 \pm 0.20^{\mathrm{b}}$ \\
Obatanpa (maize) & $166.4 \pm 0.45^{\mathrm{c}}$ & $0.00 \pm 0.00^{\mathrm{a}}$ & $4.86 \pm 0.14^{\mathrm{c}}$ \\
\hline
\end{tabular}

Means followed by the same letter in the same column are not significantly different at $\mathrm{P}=0.05$

(Student-Newman-Keul multiple comparison test).

TABLE 3. MEAN WEIGHT OF ADULT $P$. truncatus ON DIFFERENT GRAIN CULTIVARS AND SUBSTRATE TYPES

\begin{tabular}{llll}
\hline & \multicolumn{3}{c}{ Mean number of F1 generation } \\
\cline { 2 - 4 } \multicolumn{1}{c}{ Grain cultivar } & Substrate type \\
\cline { 2 - 4 } & Whole & Coarse & Fine \\
& ground grain & grain flour \\
\hline Framida (sorghum) & $2.98 \pm 0.31^{\mathrm{b}}$ & $0.00 \pm 0.00^{\mathrm{a}}$ & $2.18 \pm 0.31^{\mathrm{a}}$ \\
Mankaraga (sorghum) & $2.49 \pm 0.13^{\mathrm{a}}$ & $0.00 \pm 0.00^{\mathrm{a}}$ & $1.70 \pm 0.13^{\mathrm{a}}$ \\
Naga-White (sorghum) & $3.02 \pm 0.27^{\mathrm{b}}$ & $0.00 \pm 0.00^{\mathrm{a}}$ & $2.22 \pm 0.27^{\mathrm{a}}$ \\
Obatanpa (maize) & $4.91 \pm 0.29^{\mathrm{b}}$ & $0.00 \pm 0.00^{\mathrm{a}}$ & $4.11 \pm 0.29^{\mathrm{b}}$ \\
\hline
\end{tabular}

Means followed by the same letter in the same column are not significantly different at $\mathrm{P}=0.05$ (Student-Newman-Keul multiple comparison test). 
TABLE 4. SUSCEPTIBILITY OF GRAIN CULTIVARS TO ATTACK BY P. truncates

\begin{tabular}{llll}
\hline & \multicolumn{3}{c}{ Mean number of $F_{1}$ generation } \\
\cline { 2 - 4 } \multicolumn{1}{c}{ Grain cultivar } & \multicolumn{3}{c}{ Substrate type } \\
\cline { 2 - 4 } & Whole & Coarse & Fine \\
& grain & $0.00 \pm 0.00^{\mathrm{a}}$ & grain flour \\
\hline Framida (sorghum) & $7.14 \pm 0.58^{\mathrm{b}}$ & $3.02 \pm 0.35^{\mathrm{b}}$ \\
Mankaraga (sorghum) & $2.28 \pm 0.61^{\mathrm{a}}$ & $0.00 \pm 0.00^{\mathrm{a}}$ & $1.27 \pm 0.37^{\mathrm{a}}$ \\
Naga-White (sorghum) & $7.06 \pm 0.93^{\mathrm{b}}$ & $0.00 \pm 0.00^{\mathrm{a}}$ & $3.33 \pm 0.34^{\mathrm{b}}$ \\
Obatanpa (maize) & $19.09 \pm 1.03^{\mathrm{c}}$ & $0.00 \pm 0.00^{\mathrm{a}}$ & $7.72 \pm 0.18^{\mathrm{c}}$ \\
\hline
\end{tabular}

Means followed by the same letter in the same column are not significantly different at $P=0.05$

(Student-Newman-Keul multiple comparison test).

TABLE 5. THE PREFERENCE OF $P$. truncatus TO DIFFERENT GRAIN CULTIVARS

\begin{tabular}{ll}
\hline & Borer preference \\
\cline { 2 - 2 } Grain cultivar & Whole grain \\
\hline Framida (sorghum) & $9.80 \pm 0.15^{\mathrm{b}}$ \\
Mankaraga (sorghum) & $6.40 \pm 0.15^{\mathrm{a}}$ \\
Naga-White (sorghum) & $7.80 \pm 0.14^{\mathrm{b}}$ \\
Obatanpa (maize) & $14.80 \pm 0.10^{\mathrm{c}}$ \\
\hline Means followed by the same letter in the same column are not significantly \\
different at $\mathrm{P}=0.05$ (Student-Newman-Keul multiple comparison test).
\end{tabular}

TABLE 6. PROPERTIES OF DIFFERENT GRAIN CULTIVARS

\begin{tabular}{lllllll}
\hline & & \multicolumn{5}{c}{ Grain properties } \\
Grain cultivar & Length $(\mathbf{m m})$ & Breadth $(\mathbf{m m})$ & $\begin{array}{l}\text { Density } \\
\left(\mathbf{g} / \mathbf{c m}^{3}\right)\end{array}$ & $\begin{array}{l}1000 \text {-grain } \\
\text { weight } \mathbf{( g )}\end{array}$ & $\begin{array}{l}\text { Endosperm } \\
\text { texture (\%) }\end{array}$ & $\begin{array}{l}\text { Grain } \\
\text { hardness (N) }\end{array}$ \\
\hline Framida (sorghum) & $4.35 \pm 0.11^{\mathrm{a}}$ & $3.95 \pm 0.13^{\mathrm{b}}$ & $0.84 \pm 0.12^{\mathrm{a}}$ & $25.00 \pm 0.14^{\mathrm{a}}$ & $47.88 \pm 1.59^{\mathrm{c}}$ & $45.84 \pm 1.99^{\mathrm{c}}$ \\
Mankaraga (sorghum) & $4.57 \pm 0.13^{\mathrm{a}}$ & $3.54 \pm 0.11^{\mathrm{a}}$ & $1.05 \pm 0.11^{\mathrm{a}}$ & $26.70 \pm 0.14^{\mathrm{a}}$ & $72.20 \pm 1.12^{\mathrm{a}}$ & $82.38 \pm 3.15^{\mathrm{a}}$ \\
Naga-White (sorghum) & $4.22 \pm 0.10^{\mathrm{a}}$ & $3.87 \pm 0.11^{\mathrm{ab}}$ & $0.92 \pm 0.12^{\mathrm{a}}$ & $24.30 \pm 0.11^{\mathrm{a}}$ & $56.12 \pm 1.07^{\mathrm{b}}$ & $59.18 \pm 2.60^{\mathrm{b}}$ \\
Obatanpa (maize) & $10.77 \pm 0.18^{\mathrm{b}}$ & $8.78 \pm 0.12^{\mathrm{c}}$ & $1.24 \pm 0.14^{\mathrm{a}}$ & $257.00 \pm 0.24^{\mathrm{b}}$ & $72.20 \pm 1.12^{\mathrm{a}}$ & $298.59 \pm 8.48^{\mathrm{d}}$ \\
\hline
\end{tabular}

Means followed by the same letter in the same column are not significantly different at $P=0.05$ (Student-Newman-Keul

multiple comparison test). 
The presence of first generation adult beetles with moderate weights observed in this study suggests that sorghum grain has sufficient nutrient to support breeding by $P$. truncatus (Tables $2 \& 3$ ) because nutritional quality of a substrate is an important factor for the development of the larvae (Diane 1993). In addition to feeding on the germ, it is also possible that the beetle obtain additional nutrients through indiscriminate feeding within the grain kernels (Ramirez Martinez \& Silva 1983; Subramanyam et al. 1987; Vowotor et al. 1998).

Results from this work also showed that high-yield improved sorghum cultivars (Framida \& Naga-White) were more susceptible to attack by $P$. truncatus than on the native one (Mankaraga) (Table 4), probably because of faster development periods (Table 1). These beetles also showed higher preference for the high-yield improved sorghum cultivars than the native one (Table 5). The differences in grain hardness and endosperm texture (Table 6 ) could be a possible factor for this difference since the amount of tunneling and size of egg batches laid depends on hardness of the substrate (Li 1988). Previous studies (Demianyk \& Sinha 1988, Li 1998) recorded fewer egg deposits per period in relatively hard seeds during peak oviposition periods and consequently fewer adults emergence.

Despite its hard pericarp and endosperm, maize grain proved to be the most preferred breeding substrate for $P$. truncatus (Tables $1,4 \& 6$ ), producing high numbers of heavier adult beetles (Table $2 \& 3$ ). It is possible that the larger mean length of maize grain compared to sorghum might have resulted in the offsprings of $P$. truncatus surviving better on maize, since it provide enough space for tunneling and oviposition than on sorghum.

In conclusion, these findings revealed that $P$. truncatus can successfully complete its development on sorghum grain, with whole grain substrate and high-yield improved sorghum cultivars showing higher susceptibility compared to grain flour substrate and the native sorghum cultivar, respectively. These indicate that in the absence of its most preferred host (maize), $P$. truncatus can subsist on sorghum grain as its reservoir. It is therefore imperative to take these findings into consideration when designing biological control programmes in sorghum growing regions of sub-Saharan Africa.

\section{ACKNOWLEDGEMENT}

The authors are grateful to the Plant Protection and Regulation Services, Ministry of Food and Agriculture (PPRS/MOFA), Pokuase, Ghana, for the use of their laboratories and equipment. We thank Dr. I.D.K. Atokple from the Savannah Agricultural Research Institute (SARI/CSIR), Tamale and the Council for Scientific and Industrial Research (CSIR), Ghana, for provision of sorghum cultivars and technical assistance. This study was funded by the German Academic Exchange Service (DAAD) through the African Regional Postgraduate Programme in Insect Science (ARPPIS), West Africa Sub-regional Centre, University of Ghana, Legon-Accra.

\section{REFERENCES}

Agbaka, A. 1996. Etude biologique et possibilité de lutte intégrée contre Prostephanus truncatus (Horn) (Coleoptera: Bostrichidae) ravageur des stocks de maïs dans les milieux paysans en République du Bénin. Thèse de Doctorat de 3ième ciecle. Faculté des Sciences et Techniques de l'Université National de Côte d'Ivoire. Abidjan, 223pp.
Ayertey, J. N. \& Padi, B. 1996. Biosystematic capabilities of Ghana, with special reference to entomology. Invited paper, West African Coordination Workshop for Biosystematics, IITA, Cotonou, Benin Republic 24-26, Sept. 1996.

Bell, R. J. \& Watters, F. L. 1982. Environmental factors influencing the development and rate of increase of Prostephanus truncatus (Horn) on stored maize. Journal of Stored Product Research, 18:131-142.

Bell, A., Mück, O., Mutlu, P. \& Schneider, H. 1999. Integrated PostHarvest Protection is Worth its Money! GTZ, Eschborn, Germany.

Birkinshaw, L. A. \& Hodges, R. J. 2000. Improving IPM approaches for Prostephanus truncatus control in Africa. Post-harvest Action News, No. 3, http://www.iita.org/info/newslets.htm.

Chijindu, E. N. 2002. Effects of variety and processed forms of cassava chips on the development of Prostephanus truncatus (Horn) and Aracerus fasciculatus (Degeer). M.Phil Thesis, University of Ghana, Legon, 175pp.

Davey, P. M. 1965. The susceptibility of sorghum to attack by the weevil, Sitophilus oryzae (L). Bulletin of Entomological Research, 56: 287-297.

Demianyk, C. J. \& Sinha, R. N. 1988. Bioenergetics of the Larger Grain Borer, Prostephanus truncatus (Horn), feeding on corn. Annals of Entomological Society of America, 81:449-459.

Diane, B. 1993. Comparative investigations on the suitability of various substrates for Prostephanus truncatus (Horn). Wissenechaftlicher Fachverlag Gieben, Germany.

Dick, K. M. 1988. A review of insect infestation of maize in farm storage in Africa with special reference to the ecology and control of Prostephanus truncatus (Horn). Bulletin of the Natural Resources Institute Catham, U.K.18:22

Dobie, P. 1974. The laboratory assessment of the inherent susceptibility of maize varieties to post-harvest infestation by Sitophilus zea mais Motsch (Coleoptera, Curculionidae). Journal of Stored Product Research, 10:183-197.

Dunstan, W. R. \& Magazini, I. A. 1981. Outbreaks and new records, United Republic of Tanzania. The larger grain borer on stored products. Plant Protection Bulletin of the Food and Agricultural Organization 29:80-1.

Food and Agricultural Organization 2003. FAO Statistics Series, Production Yearbook, Rome, Italy, 57:34-39

Farrell, G. 2000. Dispersal, phenology and predicted abundance of the larger grain borer in different environments. African Crop Science Journal, 8:337-343.

Farrell, G. \& Schulten, G. G. M. 2002. Larger grain borer in Africa; a history of efforts to limit its impact. Integrated Pest Management Review, 7:67-84. 
Gwary, D. M. \& Asala, S. W. 2006. Progress of sorghum leaf anthracnose symptom types under field fungicide treatments in the Nigerian Savanna. International Journal of Agriculture and Biology, 8: 309-312.

Haines, C. P. (Ed) 1991. Insects and arachnids of tropical stored products: Their biology and identification. A training manual of the Natural Resources Institute (NRI), Catham. U.K.

Harnish, R. \& Krall, S. 1984. Further distribution of the larger grain borer in Africa. Plant Protection Bulletin of the Food and Agricultural Organization 32:113-114.

Henning-Helbig, S. 1995. Recommendations on the Use of Teretriosoma nigrescens for Biological Control of Prostephanus truncatus. GTZ, Eschborn, Germany.

Hill, D. S. 2002. Pests of stored foodstuffs and their control. Dordrecht, Kluwer Academic Publishers, The Netherlands.

Holst, N. \& Meikle, W. G. 2003. Teretrius nigrescens Lewis against larger grain borer Prostephanus truncatus (Horn) in African maize stores: biological control at work? Journal Applied Ecology, 40:307319.

Li, L. 1988. Behavioural ecology and life history evolution in the Larger Grain Borer Prostephanus truncatus (Horn). PhD Thesis, University of Reading, U.K. 229pp.

Meikle, W. G., Markham, R. H., Nansen, C., Holst, N., Degbey, P., Azoma, K. \& Korie, S. 2002. Pest management in traditional maize stores in West Africa: a farmer's perspective. Journal of Economic Entomology, 95:1079-1088.

McFarlane, J. A. 1988. Pest management strategies for Prostephanus truncatus (Horn) (Coleoptera: Bostrichidae) as a pest of stored maize grains: present status and prospects. Tropical Pest Management 34 121-32.
Pomeranz, Y., Czuchajowska, Z., Martin, C. R. \& Lai, F. S. 1985. Determination of corn hardness by the Stenvert Hardness Tester. Cereal Chemistry, 62:108-112.

Ramirez Martinez, M. \& Silva, B. 1983. Deterioration and damage produced in corn grains in Mexico by Prostephanus truncatus (Horn). Biodeterioration, 5:582-591.

Roux, P. W. J. 1999. Larger grain borer: further developments. Plant Protection News of the Plant Protection Research Institute, South African 55:3-4.

Santhoy, G. \& Rejesus, B. B. 1975. The development rate, body weight and reproduction capacity of Sitophilus zeamais (Motsch.) reared on three natural hosts. Physiological Entomology, 2:311-321.

SAS Institute Inc. 1989. SAS/STAT User's Guide, Version 6, 4th edition. Cary, North Carolina, USA.

Subramanyam, B. H., Cutkomp, L. K. \& Kouable, B. 1987. Effects of short-term feeding by adults of Prostephanus truncatus (Horn) on shelled maize. Journal of Stored Product Research, 33:151-155.

Vowotor, K. A., Miekle, W. G., Ayertey, J. N., Borgemeister, C. \& Markham, R. H. 1998. Intraspecific competition between the larvae of the larger grain borer Prostephanus truncatus (Horn) (Coleoptera: Bostrichidae) within maize grains. Insect Science and its Application, 18:171-175.

Zar, J. H. 1999. Bioststatical Analysis, $4^{\text {th }}$ ed. Prentice Hall, Inc., Upper Saddle River, New Jersey. 